DOI: $10.26650 / \mathrm{jes} 181208$

\title{
Esra ÖZSÜER, Türkokratia, Kronik Kitap, 2018, 375, ISBN 978-975-2430-73-3
}

\section{Emre KURBAN*}

Kronik Kitap, though established in 2016, has been publishing credible works of scholars for history researchers' concern since the beginning. Mainly history books comprise great deal of the collection of the publishing house that produces works of social sciences. Dr Esra Özsüer's book titled "Türkokratia" is an exemplar of the qualified and original studies which can be named one by one. The book tackling the image of Turks in Europe was presented to the reader in September, 2018.

Having been working at the Department of Eurasian Studies, Istanbul University Research Instute of Turkology; Dr Esra Özsüer examined the image of Turks in the nation forming process of Greeks through the example of Greece in her book Türkokratia. The name of the book Türkokratia is a Greek term expressing the Ottoman autonomy from the year 1453 onwards. The period connotates a 400 -year dark age consisting in a peujorative meaning for Greeks. The book exactly based its inquiry in this period in order to examine the Turkish image.

Composed of five chapters, the book has a theoretical and conceptual introduction. The first chapter "Image" goes around the concept on a philosophical and theoretical basis thereby also making historical exemplifications. The examples are partly obtained from Turkish history and illuminate the Turkish image in the course of history.

The theoretical inquiry proceeds in the second chapter. In the second chapter titled "The Other and Identity", it is the concept of otherness that was firstly addressed. The making of an identity and identification are the problems stressed though the concept of

\footnotetext{
${ }^{*}$ Res. Asst., Istanbul University Research Institute of Turckology, e-mail: emre.kurban@istanbul.edu.tr, https://orcid.org/0000-0003-0499-325X
} 
other. In the chapter, touching upon cliches and prejudices, the concept of other is examined from past to present and the Black and the Jewish are considered as the two others in the history. As a follow-up chapter of the first, it is -together with the first chapter- an endeavor toward illuminating the role of "Image" in making of the "Other", and the role of "Other" in identity formation.

The Turkish Image in the Grip of the Western Orientalism is the third chapter of the book. It is a transitory chapter from theoretical inquiry to full-fledged historiography. It starts with an understanding of Islam and muslims flourished in western minds as well as taking on the othering of East as muslim in Western agenda. The central discussion here is the fear of Muslims in Europe, which was given rise by the dramatic expansion of Islam and the Muslim image that were made of that fear is also stressed. The center of Christianity, The Mediterrenean Sea become the border between the Christian Europe and the Muslim East.

The fear flourished in the West is not Arab-centered but rather Islam centered since the identity was defined by religion. The coming forward of Turks as a rising power in the Islamic world leads to the emergence of an image as "Muslim Turk" in the West. The chapter touches upon the Battle of Manzikert in 1071 and conquest of Anatolia which received attention of Muslim Turks by the West. Contrary to the established narrative it is pointed out that the image of the Terrible Turk historically stretches further down the conquest of Anatolia and it elucidates the effects of the Islamification of Anatolia on Western mentality. The formation of the fear-based image of Terrible Turk takes its fullest form by the Conquest of Istanbul in 1453 and also rapid expansion of Turks further into European lands. The chapter illuminates the fear-based formation of Turkish image in relation to the fear of losing religious identity.

The fourth chapter of the book is Türkokratia. It is longest and most important chapter which gave the book its name. It mainly deals with the period of Türkokratia that is used for the 400-year dominion of Ottoman Empire from year 1453 and the nation-building of the Greek.

In the fourth chapter, it is concerned with the transitorty period from 18th century world to the process of Greek independence. In Hobsbawn's words, the period from the last quarter of 18th century until the end of the first half of 19th century was named "The Age 
of Revolutions". The world underwent far-reaching political, social and economic transformations in the period. One of the key elements is French Revolution and following rapid wave of nationalism. The key notion of nationalism that consisted in the French Revolution gave rise to nationalist awakenings of the peoples that live within the borders of multi-national empires. And the Greek were the first of those who gained their independence after the revolution.

The Greek who stood up against the Ottoman rule in 1821 achieved their independence as a result of the 10-year struggles. Democracy, freedom and equality were the key concepts of Greek Indepence, whose historical origins were obtained from Ancient Greek Civilization. The key concepts that are also embraced by the West gave rise to a deep sympathy and support towards the Greek. Having formed a Megali Idea (Great Idea) for itself, Greece oriented its ideal to be the state of the whole Greek nation. Being established as a nation-state, Greece was required to engage in a process of nation building. Greeks obtained the Ancient Greek ideal as its historical origin and predicated the historical root of nation-state on it. Because it was the movements of Classicism and Romanticism that were dominant in the world. Greece defined the period from its capture by the Romans in $145 \mathrm{BC}$ (Romeokratia) to Greek Rebellion in 1821 as the period of yoke. The 2000-year gap between Ancient Greece and the nation-state led to an obvious contraction regarding the continuity of Ancient Greek Civilization. Thereafter Greece also adopted the Byzantium by the schism of Greek National Church and Phanariot Roman Patriarchy by the last quarter of the 19th century in order to fill in the 2000-year historical gap on a large scale.

The year 1453 is an immense historical tragedy for Greek nation. The Greek have lost their capital city and the state by the capture of Istanbul by Turks in 1453 . However old myths concerning the recapture of Istanbul started circulating among the people in the process of independence war and Megali Idea united with Byzantium. The utmost importance of Haghia Sophia and Istanbul in Greek's religion and history made them fall into these dreams.

Greece took aim at being a western state at the same time showing an examplary role as a kingdom for the east, therefore they targeted at actualization of the ideal expressed in the symbol of two-headed eagle of Byzantium.

The Greek, in their nation-building process, determined their "Other" as Turks 
whose rule lasted 400 years over them. Turks were the perfect candidate for the "Other" for Greeks lived under the Ottoman rule for 400-years and Turks were the main forces that put an end to Byzantium. Nevertheless there was almost no prejudice or negative stereotype against Turks prior to the Greek rebellion. Turks were considered as Muslim in the collective memory of Greeks. The Turk that was occasionally mentioned in Greek folk songs which played a key role in transmission of national culture did not have national but only religious connotations. The western perception of Turks gradually leaked into the Greek mentality in the process of nation-building and making of the "Other" via the enlighthenment and romantic ideologoues and the image of Terrible Turk thus found its place in Greece.

In conclusion, the Turkish image that flourished in Greek imagination is western oriented and artificial. As a result of the marginalization in nation forming process Greek nation and Greek nationalism emerged and picked out Turks as the "Other". Their enthusiasm for recapturing Anatolia and Istanbul gave birth to Megali Idea that was crucial for their identity, yet the project collapsed in the year 1922. That collapse were memorialized as a triumph by Turks as for the Greek another tragic memory. 